IRA-International Journal of Management \& Social Sciences

ISSN 2455-2267; Vol.06, Issue 03 (2017)

Pg. no. 467-485

Institute of Research Advances

https://research-advances.org/index.php/RAJMSS

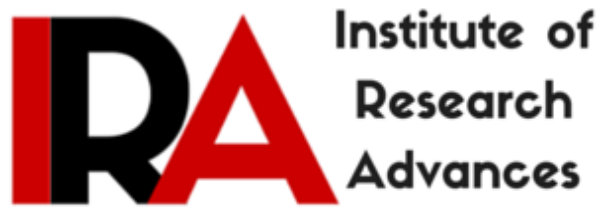

\title{
Performances of the Least Developed Countries under Neo-liberal Regimes: Implications for the implementation of Agenda 2030 for Sustainable Development
}

\author{
Dr. Melake Tewolde $(\mathrm{PhD})$ \\ Department of Economics \\ College of Business and Economics, Halhale \\ P.O. Box 12492, Asmara, Eritrea.
}

Type of Review: Peer Reviewed.

DOI: http://dx.doi.org/10.21013/jmss.v6.n3.p12

\section{How to cite this paper:}

Tewolde, M. (2017). Performances of the Least Developed Countries under Neo-liberal Regimes: Implications for the implementation of Agenda 2030 for Sustainable Development. IRA-International Journal of Management \& Social Sciences (ISSN 2455-2267), 6(3), 467485. doi:http://dx.doi.org/10.21013/jmss.v6.n3.p12

(C) Institute of Research Advances

\section{(cc) EY-NC}

This work is licensed under a Creative Commons Attribution-Non Commercial 4.0 International License subject to proper citation to the publication source of the work.

Disclaimer: The scholarly papers as reviewed and published by the Institute of Research Advances (IRA) are the views and opinions of their respective authors and are not the views or opinions of the IRA. The IRA disclaims of any harm or loss caused due to the published content to any party. 


\section{ABSTRACT}

The Least Developed Countries (LDCs) have implemented neoliberal policies such as trade liberalization, privatization of public enterprises, and currency devaluation with the expectation to promote their economic growth and development by capturing the gains from international trade through a more efficient allocation of resources and increased private investment. Twenty one countries (constituting 44\%) have been designated LDCs since 1971, the introduction of the category for the first time by the United Nations (UN). Development experiences of the LDCs indicate that neoliberal policies are not adequately addressing their development challenges. The LDCs are still locked into a low equilibrium trap characterized by fragile economic growths, distorted structural transformation, low domestic resource, high dependence on external financing, high dependence on primary commodity exports, high external debt burden and debt services and low human development. The LDCs must thus shift to a developmental state approach to strategically integrate into the world economy and to build their productive capacities and to enhance their structural transformation which could lead the countries along the path of sustained economic growth to meet the Sustainable Development Goals (SDGs) by 2030.

The implications for the implementation of Agenda 2030 for sustainable development are that:

(i) The LDCs have to extensively tap their domestic savings potentials and investments to reach $25 \%$ or more of their Gross Domestic Product(GDP) to sustain 7\% -8\% growth rates per annum that will have a great impact on poverty reduction in line with the sustainable development goal 1 (SDG1). (ii) The LDCs have to select a few SDGs which are of high national priorities and synchronize them with their respective national development plans and determine the financing needs for the implementation of the selected SDGs. (iii) cancellation of external debt of the LDCs by the creditors in order to release resources needed for their investments to achieve the SDGs (iv) replacement of foreign aid by market access for the LDCs products to increase their foreign exchange earnings needed for building their productive capacities. (v) Maintaining peace and stability and resolving conflicts to release resources needed for their productive investment.

Key words: Least developed countries, Neoliberal policies, Development challenges, Developmental state, Sustainable Development goals.

\section{INTRODUCTION}

With the emergence of colonialism, the economies of the colonized countries were integrated into the world capitalist system within which the countries functioned primarily as a source of raw materials for the industrial production of the developed countries (Farah, Kiamba and Morongo, 2011). Following the end of the Second World War, many newly independent countries commonly known as developing countries emerged. The newly independent nations, however, had no adequate human capital and other resources needed to enhance their development (Alemayeho, 2000). They were in a state of structural atrophy characterized by underdevelopment: low per capita income, low savings and investment, vastly underdeveloped infrastructure, weak industrial and technological base, inadequate human capital, high incidence of poverty and high economic vulnerability to external shocks (UN, 2015). However, there was an overwhelming sense of optimism both in the newly independent countries and the international community that the countries would achieve rapid economic growth and structural transformation that would ensure a high quality of life for their people (UN, 2010). To these ends, in the 1950s and 1960s, most developing countries adopted Import Substitution Industrialization (ISI) strategy in which their governments had leading roles in guiding the development process of their economies (Kumssa and Jones, 2015).

Despite the social and economic difficulties faced during their early post- independence period, many developing countries showed some progress in their economic, social and human development 
(Alemayeho, 2000). In some developing countries, however, the level of progress in terms of economic growth and poverty reduction was below the expectation. In 1971, the category- Least Developed Countries (LDCs) was designated for the countries which showed slow socio-economic progress (SESRTCIC, 2006). The least developed country status required collaborative support of the international community to deal with their development challenges (UN, 2015). With the worsening of their macroeconomic crisis and increasing poverty, many developing countries including the LDCs embarked on Structural Adjustment Programs (SAP) whose essence is neo-liberalism which is applied through implementing neoliberal policies (Haque, 1999). The neo-liberal policies implemented by the LDCs are predominantly forwarded by external donors. The policies are then uncritically imposed on the LDCs as a condition for foreign aid, external debt cancellation and preferential market access (Wenjing 2012; Haque, 1999; Lapeyre, 2004,). The LDCs have remained underdeveloped despite decades of conceptualising, formulating and implementing neo-liberal policies. They are still at the lowest stage in the development continuum of the international community, while faced with multiple development challenges (Babatunde, 2009; Siddiqui, 2012).

\section{PROBLEM STATEMENT}

In 1971, the United Nations General Assembly in recognition of the widespread poverty and weakness of their economic, institutional and human resources often compounded by geophysical handicaps approved the first list of LDCs, which at that time included 24 countries (SESRTCIC, 2006, p.51; UNCTAD, 2005, p.2). The designation of least developed country is periodically adjusted based on three key criteria: (i) low Gross Domestic Product (GDP) per capita, (ii) weak human resources, and (iii) a high degree of economic vulnerability (UNCTAD, 2015). The LDCs differ in their economic, social natural resource, industry, infrastructure, human resources, population and geographic size (UNIDO, 2016, p.7). They, however, face similar challenges such as low levels of socio-economic development, weak human and institutional capacities (UNIDO, 2016). In some LDCs, political instability and internal and external conflicts hamper their development. The landlocked and small island LDCs particularly have immense development challenges (SESRTCIC, 2006). Since 1971, the number of LDCs has increased from 24 to 48 in 2015. To date, only four countries, namely Botswana, Cape Verde, Maldives and Samoa have graduated from the LDCs status (UNCTAD, 2015, P. iii). Twenty one LDCs, constituting $44 \%$ are those countries which have been designated least developed country status by the United Nations since 1971 (UN, 2016).

Since 1980s, the LDCs have liberalized their economies with the expectation to enhance their economic growth by capturing the gains from international trade through a more efficient allocation of resources and increase in private investments and technical progress (Ackerman and Gallagher, 2008; Asiedu, 2013; Babatunde, 2009). Neo-liberal regimes in the LDCs have increasingly been forced to adopt rules and standards of World Trade Organization (WTO) and run their economies under a system of conditionalities (UNCTAD, 1999). The conditionalities have severely constrained the freedom of the governments in making choices on their economic policies, while creating vast space for 'donor dirigisme'. As a result, the governments of the LDCs have lost effective control over their economic policy making to international financial institutions (Lapeyre, 2004; ECA, 2013).

While liberalizing their economies, the LDCs have also faced formidable development challenges because of three reasons. First, developed countries continue to protect their markets and their sensitive products, particularly agricultural products (Hammouda and Jallab, 2003, p.3). Second, the continuing rise of export-oriented manufacturing industry across Asia, including China and India have made the emergence or the survival of domestic manufacturing production in the LDCs more difficult (Dercon, 2007, p.6). Third, the LDCs have been unable to build their productive capacities due to external and internal structural constraints (Khor, 2000, p.9). The LDCs which constitute 12 per cent of the world's population, around $50 \%$ of their population still face extreme poverty. These countries account for less than 2 per cent of the world's GDP, and around one per cent and 0.5 per cent of world trade 
in goods and services respectively (UN, 2011, p.11; Bhattacharya and Hossain, 2011, p.4). The development challenges of the LDCs have also been complicated by the rapid growth rates of their population which demand huge resources, particularly for social services like health care and education. In 2015 the population of the LDCs reached more than 954 million and in 2030 the population is expected to reach more than 1.3 billion (UNIDO, 2016, p.32).

In September 2015, the United Nations adopted the 2030 Agenda for Sustainable Development. The 2030 Agenda contains 17 Sustainable Development Goals (SDGs) with 169 associated targets (UN, 2015, p.6). These are: Goal 1. End poverty in all its forms everywhere; Goal 2. End hunger, achieve food security and improved nutrition and promote sustainable agriculture; Goal 3. Ensure healthy lives and promote well -being for all at all ages; Goal 4. Ensure inclusive and equitable quality education and promote lifelong learning opportunities for all; Goal 5. Achieve gender equality and empower all women and girls; Goal 6. Ensure availability and sustainable management of water and sanitation for all; Goal 7. Ensure access to affordable, reliable, sustainable and modern energy for all; Goal 8. Promote sustained, inclusive and sustainable economic growth; full and productive employment and decent work for all; Goal 9. Build resilient infrastructure, promote inclusive and sustainable industrialization and foster innovation; Goal 10. Reduce inequality within and among countries; Goal 11.Make cities and human settlements inclusive, safe, resilient and sustainable; Goal 12. Ensure sustainable consumption and production patterns; Goal 13. Take urgent action to combat climate change and its impacts; Goal 14. Conserve and sustainably use the oceans, seas and marine resources for sustainable development; Goal 15. Protect, restore and promote sustainable use of terrestrial ecosystems, sustainably manage forests, combat desertification, and halt and reverse land degradation and halt biodiversity loss; Goal 16. Promote peaceful and inclusive societies for sustainable development, provide access to justice for all and build effective, accountable and inclusive institutions at all levels; and Goal 17. Strengthen the means of implementation and revitalize the Global Partnership for Sustainable Development (UN, 2015, p14)

The SDGs have four aspect of development: economic, social, environmental and security. The LDCs account for some $40 \%-50 \%$ of global financial needs to meet the SDGs in terms of extreme poverty reduction and increased access to water and electricity (UN, 2013, p.5). The LDCs have also huge infrastructure deficiency in key sectors, such as electricity, roads and airports (UN, 2013, p.5). The implementation of the SDGs in the LDCs would require huge investments. However, their ability to finance the SDGs is very limited (UNCTAD 2015, p. 15). The LDCs lack resources because they are still far below the threshold level of development in terms of human, agricultural, industrial, infrastructural, and all these have hindered them from seizing the opportunities of economic liberalization (Abubakar, 2010, p.166). A major challenge confronting the LDCs is mobilization of adequate domestic resources to meet the investments needs for building their productive capacities and transforming their economies that would help them to achieve the SDGs by 2030.

\section{OBJECTIVE OF THE STUDY}

International trade by expanding markets for goods and services of developing countries can be a driving force for growth and development. However, sustained economic growth requires not just implementing neo-liberal policies but also accumulation of physical, human capital, technological progress and well developed productive capacities (Bergés, 2007; Taleb, 2012; Jones, 1998; UNCTAD, 2006; Montes, 2014). Within a liberalized trade environment, the LDCs would be required to give a high priority to the building of critical mass of viable and competitive productive capacities in their agriculture, manufacturing and services (UNCTAD, 2010).

Building productive capacities in the LDCs is necessary for a number of reasons. First, it is essential for overcoming the supply constraint of their exports. Second, it helps to enhance technological transfer in their economies. Third, it reduces their vulnerability to external shocks (UNCTAD, 2005). The best 
approach to developing productive capacities in the LDCs is through prudent macroeconomic management, increasing investments in agriculture, manufacturing industry, human resource development, infrastructural development, promotion of entrepreneurship and innovation (Dercon, 2007); UNCTAD , 2010). Development of productive capacities in the LDCs is also a critical factor for the achievement of the SDGs, particularly SDG 1, SDG 2, SDG 8: and SDG 9 (UN, 2015, p.14). Thus, the fundamental priority of the LDCs governments has to be the formulation and implementation of their national development strategies and securing ownership of their development programs to achieve the envisaged GDP growth rate of 7 per cent per annum as stated in SDG target 8.1 ( UN, 2015 , p.15). In the 2030 Agenda for sustainable development, international trade is treated as engine of economic growth and development as indicated in SDG target 17.11 which underpins the need to increase exports of developing countries, in particular with a view to doubling the LDCs share of global exports by 2020 (UN, 2015, p.27).

Development experience of the LDCs in a neo-liberal policy environment is an empirical question. The overall objective of the paper is thus to critically assess development experience (performance) of the LDCs over the past decades. The specific objectives are to:

1) Critically analyse the performances of the LDCs using different indicators of development;

2) Analyse the major development constraints faced by LDCs while adopting neoliberal approach to their development; and

3) Analyse the implications for LDCs for the implementation of the 2030 Agenda for sustainable development.

In line with the problem statement and objective of the study, this paper aims to address the following questions: (i) what does the evidence tell us about the LDCs' performances? (ii) How can the good or poor performance of the LDCs under neo-liberalism be explained? (iii) What are the implications for the LDCs and international community as the LDCs enter into a new phase of implementing SDGs?

\section{METHODOLOGY}

The study dwells on extensive literature review to gather secondary data from various sources including research reports, publications of academic institutions, relevant documents of international organizations and national policy documents relevant textbooks as well as the internet. The secondary data are contextualized and analyzed to suit the objectives of the study.

Following sections 1-4, (introduction, problem statement, objectives and methodology), Section 5 deals with conceptual framework: Neo-liberal policies and development of LDCs Section 6 is the main body of the paper; it deals with the critical analysis of the performances of the LDCs' economies under neo-liberal regimes. Section 7 is an extension of the previous sections and focuses on discussion and the implications for the implementation of the SDGs by LDCs.

\section{CONCEPTUAL FRAMEWORK: NEO-LIBERAL POLICIES AND DEVELOPMENT OF LDCs}

Every conceptual framework on trade and development is distinguished by its perception of the objectives of development and the trade policies it prescribes to stimulate socio-economic development (Uwa, Lanrewajuu and Ojeme, 2014). Neo-liberalism is an ideological position based on strong beliefs that economic growth is enhanced by promotion of free trade based on comparative advantage and by limiting the role of the state in regulating an economy (Nayyar, 2006;Haque, 19996 ;King, 1987; Toye, 1991). This in effect is a shift from state-led to market-oriented policies; it is also a shift in the ways in which development problems are framed and in the types of explanations through which policies are justified. Neo-liberalism as a policy paradigm includes a set of interrelated policies which range from trade liberalization, to privatization of public enterprises, to reduced controls on capital movements, to global free-trade agreements, to deregulation of credit or labour markets, to fulfilling IMF conditionalities and to new regimes of intellectual property (Evans and Sewell, 2011, p.5). These pro-market policies are 
often advocated in the name of efficiency in resource allocation, macroeconomic stability, economic growth and competitiveness (Haque, 1999; Afzal, 2012).

Although, the extent to which the LDCs have made socio-economic progress in trade-led development is an empirical issue, it can be argued that trade liberalization and integration into the global economy is a necessary but not a sufficient condition for development. Trade liberalization is certainly part of the development process and is a very important policy issue. Economic development requires: (i) macroeconomic policies that are oriented towards growth and job creation, including fiscal and monetary policies that give high priority on growth, employment and development; (ii) long-term development policies directed to the development of productive capacities in agriculture, industry and services and the development, transfer and access to affordable technology ( South Centre, 2013, p.8). The LDCs' future development will to a greater extent be determined by their trade relations with the rest of the world. However, trade-led development has weakened structural transformation and productive capacities in the countries (UNCTAD, 2004, p.80).

Without industrialization, structural transformation and building of productive capacities the LDCs do not seem to avoid further marginalization in the $21^{\text {st }}$ century (ADB, 2004). The LDCs thus need autocentric development based on structural transformation and building of productive capacities. Structural transformation underlines the importance of an export-oriented development strategy that enhance sustained economic growth and export diversification based on the mobilization of domestic and external resources without generating external dependence and international indebtedness (ADB, 2003). To these ends, the LDCs need a developmental state which gives top priority to economic development in government policies and seeks to design policies and institutions that would promote their economic growth, structural transformation and productive employment (Leftwich, 2000; UNCTAD, 2010). The development of productive capacities involves three basic processes: (i) accumulation of physical, human and organizational capital, (ii) technological progress and (iii) structural transformation (UNCTAD, 2004, p.79). It is through structural transformation and the development of their productive capacities that the LDCs will be able to rely increasingly on their domestic resources mobilization to finance their economic growth, to reduce aid dependency and to attract private capital inflows of a type that enhance their development process (UNCTAD, 2006). The developmental state approach by expanding their policy space would enable the LDCs to achieve the expected positive benefits of trade liberalization in terms of sustained economic growth, poverty reduction, and structural transformation and export diversification (UNCTAD, 2004). Development of productive capacities would be particularly important for the LDCs during the next 14 years because they are at a critical moment of implementation of the SDGs.

\section{PERFORMANCES OF THE LDCS UNDER NEO-LIBERAL REGIMES}

This section deals with the critical assessment of the performance/development experiences of the LDCs as a group while following neo-liberal approach to their development using ten indicators: (i) Real Gross Domestic Product growth rate. (ii) Structural change and sectoral employment. (iii) Composition of exports. (iv) Foreign exchange earnings from manufacturing sector. (v) Trend of current account balance. (vi)External resource gap. (vii) Dependence on Official Development Assistance. (viii) Inflow of foreign direct investments and their sectoral orientation. (ix) External debt burden and (x) Human Development Index (HDI).

\subsection{Real Gross Domestic Product growth rate}

Economic growth is the most powerful instrument for reducing poverty and improving the quality of life in the LDCs. The real GDP growth of the LDCs as a group was 7.4\% during the period 2002-08, similar to the growth rates of Other Developing Countries (ODCs), which was 7\% (See Table 1). The real GDP growth rates showed a declining trend during the period 2010-2015, reaching $5.2 \%$ in 2015. 
Sustainability of the growths in the LDCs remained fragile because the growth rates are dependent on commodity prices, external financing and weather conditions. Neo-liberal policies implemented in the LDCs led to the sudden and extreme trade liberalization policies that reduced tariffs, which subsequently resulted into the closure or reduction of small farms and local industries. Neo-liberal policies which focus on expenditure reducing are growth-contracting because they limit public investments in the social and productive sectors, particularly agriculture and manufacturing industries (South Centre 2013). The growth rates in the LDCs were far below their potential growth rates because of inadequate domestic saving and investment. Simulation conducted on the LDCs' growth trajectories showed that the LDCs have the potential to reach growth rates of $7.5 \%$ per annum that would have great impact on their poverty reduction (UNCTAD, 2006, p.88). Over the study period, growths in the LDCs were non- transformative or pro-poor as the growths were not translated effectively into substantial poverty reduction and improvement of human development through trickledown effects. Around 75 per cent of the least developed countries' population lived in poverty; nearly 30\% of their population were undernourished, and nearly two-thirds of the population had no access to clean water supply and sanitation facilities (UN, 2011, p.11; UNCTAD, 2014, p.4). Poverty, hunger and food insecurity, together with a very unequal distribution of income, land and other material goods, provide a fertile ground for grievances that can be exploited by individuals and groups with a desire to cause conflict (Pinstrup-Andersen and Shimokawa, 2008).

Table 1: Real GDP growth Rate in LDCs, other developing countries and developed countries, 2002-2015 (percent)

\begin{tabular}{|l|c|c|c|c|c|c|c|}
\hline & $\mathbf{2 0 0 2 - 0 8}$ & $\mathbf{2 0 1 0}$ & $\mathbf{2 0 1 1}$ & $\mathbf{2 0 1 2}$ & $\mathbf{2 0 1 3}$ & $\mathbf{2 0 1 4}$ & $\mathbf{2 0 1 5}$ \\
\hline LDCs & $\mathbf{7 . 4}$ & $\mathbf{5 . 7}$ & $\mathbf{4 . 5}$ & $\mathbf{7 . 2}$ & $\mathbf{6 . 1}$ & $\mathbf{5 . 5}$ & $\mathbf{5 . 2}$ \\
\hline African LDCs \&Haiti & 8.0 & 5.4 & 4.7 & 7.7 & 6.1 & 5.5 & 5.0 \\
\hline Asian LDCs & 6.7 & 6.3 & 4 & 6.5 & 6.0 & 5.4 & 5.6 \\
\hline Island LDCs & 3.9 & 6.9 & 11. & 6.1 & 4.8 & 4.4 & 5.0 \\
\hline ODCs & 7.0 & 7.8 & 5.8 & 4.8 & 4.8 & 4.4 & 4.4 \\
\hline All developing countries & 7.7 & 7.8 & 5.7 & 4.9 & 4.8 & 4.5 & 4.4 \\
\hline Developed countries & 2.4 & 2.6 & 1.5 & 1.1 & 1.3 & 1.7 & 2.3 \\
\hline
\end{tabular}

Source: UNCTAD 2015, p.3

\subsection{Structural change and sectoral employment}

As shown in Table 2, the share of agriculture in total output/GDP in the LDCs decreased from $33 \%$ in 1991 to $25 \%$ in 2012, much higher than the share of agriculture in GDP in the ODCs, which constituted $8 \%$ in 2012. The decline in the share of agriculture in the LDCs was not because of structural change in favour of manufacturing sector but because of de-agrarianization, the shrinking of the contribution of the agricultural sector due to decline in the public and private investments in the agricultural sector. The share of industry increased from $23 \%$ in 1991 to $31 \%$ in 2012, mainly because of the relative increase in the contribution of non-manufacturing industries such as mining, utilities and construction (UNCTAD, 2010, p.11). The service sector had the greatest share in GDP, although its share decreased marginally from $45 \%$ in 1991 to $44 \%$ in 2012.

Table 2: Sectoral composition of output, 1991-2012 (percent)

\begin{tabular}{|l|c|c|c|c|c|c|c|c|c|}
\hline & \multicolumn{3}{|c|}{ Agriculture } & \multicolumn{3}{c|}{ Industry } & \multicolumn{3}{c|}{ Services } \\
\hline & $\mathbf{1 9 9 1}$ & $\mathbf{2 0 0 0}$ & $\mathbf{2 0 1 2}$ & $\mathbf{1 9 9 1}$ & $\mathbf{2 0 0 0}$ & $\mathbf{2 0 1 2}$ & $\mathbf{1 9 9 1}$ & $\mathbf{2 0 0 0}$ & $\mathbf{2 0 1 2}$ \\
\hline LDCs & 33 & 30 & 25 & 23 & 27 & 31 & 45 & 43 & 44 \\
\hline African LDCs\& Haiti & 34 & 32 & 26 & 23 & 28 & 34 & 43 & 40 & 40 \\
\hline
\end{tabular}


IRA-International Journal of Management \& Social Sciences

\begin{tabular}{|l|c|c|c|c|c|c|c|c|c|}
\hline Asian LDCs & 30 & 26 & 22 & 21 & 27 & 27 & 48 & 47 & 51 \\
\hline Island LDCs & 31 & 30 & 13 & 22 & 25 & 64 & 42 & 47 & 44 \\
\hline ODCs & 11 & 10 & 8 & 38 & 40 & 40 & 51 & 51 & 52 \\
\hline DC & 1 & 1 & 2 & 28 & 26 & 23 & 71 & 72 & 75 \\
\hline
\end{tabular}

Source: UNCTAD 2014, Table 12, p. 65

As shown in Tables 2 and 3, agriculture in the LDCs employed 65\% of their labour force in 2012, its contribution to GDP, however, was lesser than the service sector, which employed $26 \%$ of their labour force. The trend of production structure in the LDCs as a group was not associated with normal structural transformation. In the normal process of economic transformation, economies begin with a high share of agriculture in GDP, and as incomes rise, the share of agriculture declines and that of manufacturing rises. This process continues until the economy reaches a relatively high level of development, where both the shares of agriculture and manufacturing to GDP fall and that of the services rise ( Todaro and Smith, 2011). Over the past decades, the LDCs moved from state in which their agriculture had a very high share of GDP to one in which the service sector, particularly lowproductivity activities within the service sector, dominates the GDP. This transition took place without any significant development of manufacturing. Therefore, the LDCs as a group experienced jobless growth over the past decades. Moreover, the growths had little impact on the development of their productive capacities, which requires investment rates of $25 \%$ or above of their GDP to sustain $7 \%-8 \%$ growth rates, which most analysts consider have a high impact on reducing poverty. Although it is not easy to identify a single strategy for the development of productive capacities in LDCs owing to the heterogeneity of their economies, there are two factors that need to be taken into account: (i) the development of productive capacities should be market-oriented. (ii) a successful market-based approach to developing productive capacities must increase the policy space of the LDCs' governments in order to promote their structural transformation (UNCTAD, 2011).

Table 3: Sectoral composition of employment, 1991-2012 (percent)

\begin{tabular}{|l|c|c|c|c|c|c|c|c|c|}
\hline & \multicolumn{3}{|c|}{ Agriculture } & \multicolumn{3}{c|}{ Industry } & \multicolumn{3}{c|}{ Services } \\
\hline & $\mathbf{1 9 9 1}$ & $\mathbf{2 0 0 0}$ & $\mathbf{2 0 1 2}$ & $\mathbf{1 9 9 1}$ & $\mathbf{2 0 0 0}$ & $\mathbf{2 0 1 2}$ & $\mathbf{1 9 9 1}$ & $\mathbf{2 0 0 0}$ & $\mathbf{2 0 1 2}$ \\
\hline LDCs & 74 & 71 & 65 & 8 & 8 & 10 & 18 & 21 & 26 \\
\hline African LDCs \& Haiti & 76 & 75 & 70 & 6 & 5 & 7 & 18 & 20 & 24 \\
\hline Asian LDCs & 70 & 65 & 57 & 11 & 11 & 14 & 18 & 24 & 30 \\
\hline Island LDCs & 66 & 57 & 55 & 8 & 10 & 11 & 25 & 33 & 34 \\
\hline ODCs & 53 & 46 & 34 & 20 & 20 & 25 & 27 & 33 & 41 \\
\hline DC & 7 & 5 & 4 & 31 & 27 & 23 & 62 & 67 & 74 \\
\hline
\end{tabular}

Source: UNCTAD 2014, table 11, p. 64

\subsection{Composition of exports}

In a neo-liberal policy environment, the LDCs aim to improve their export specialization through increased competitiveness of existing activities and continue their export diversification by expanding into new activities. During the period 2012-2014, the total value of exports of the LDCs as a group was USD 207,389.20 million, much lesser than those of the ODCs, which was USD 8,163,939.70 million ( see Table 4). Overall, the structure/composition of the export earnings of the LDCs reflects the dominance of primary sector. During the period 2012-2014, 76.8\% of the export earnings in the LDCs were generated from the primary commodity exports, much higher than export earrings of the ODCs from export of primary commodities, which was $36.5 \%$ of their total export earnings. The export earnings from manufacturing sector in the LDCs constituted $22.7 \%$, much lesser than those of the ODCs, which was $62.5 \%$. Table 4 suggests that the dependence on a few commodities has traditionally been a prominent feature of the LDCs' export structure. Therefore, there is no doubt that the exports of those commodities 
play a critical role in the prospects of growth and development in the LDCs. Yet, the large share of primary commodities in output and exports brings about a significant exposure of the LDCs' economies to the risks of external shocks, such as the fluctuating trends in international prices and/or adverse weather conditions, with negative effects on their economic growth. The implication is that the LDCs need to focus on increasing public and private investments for building their productive capacities and enhancing their structural transformation. Such approach would lead to a broad-based and employment creating economic growth, poverty reduction and export diversification.

Table 4: Product composition of merchandise exports 2012-2014 (\$ million dollars)

\begin{tabular}{|l|c|c|c|c|}
\hline & $\begin{array}{c}\text { Total exports } \mathbf{( \$} \\
\text { Million) }\end{array}$ & $\begin{array}{c}\text { Primary } \\
\text { commodities }(\boldsymbol{\%})\end{array}$ & $\begin{array}{c}\text { Manufactured } \\
\text { goods (\%) }\end{array}$ & $\begin{array}{c}\text { Unallocated } \\
(\mathbf{\%})\end{array}$ \\
\hline LDCs & $207,389.20$ & 76.8 & 22.7 & 0.5 \\
\hline African LDCs \&Haiti & $146,549.40$ & 92.5 & 7.2 & 0.4 \\
\hline Asian LDCs & $60,255.30$ & 38.6 & 60.7 & 0.7 \\
\hline Island LDCs & 584.50 & 84.3 & 5.5 & 10.2 \\
\hline ODCs & $8,163,939.70$ & 36.5 & 62.5 & 0.9 \\
\hline
\end{tabular}

UNCTAD, 2015, Table 13, p.13

\subsection{Foreign exchange earnings from manufacturing sector}

Economic strength of developing countries can be assessed in terms of the global share of the foreign exchange earnings from the manufacturing sector and the share of the sector in GDP and the level of employment. As shown in Table 5, the value of exports from the manufacturing sector in the LDCs increased from USD 7 billion in 1995 to USD 39 billion in 2013. The export earnings of the LDCs compare unfavourably with the ODCs, which were USD 24 billion and USD 372 billion in 1995 and 2013 respectively. The marginalization of the LDCs in the world market is clearly indicated by the fact that the countries' share was less than one percent of the world value of the manufacturing exports during the period 1995-2013.

Table 5: Value of manufacturing exports by development group, selected years 1995-2013 (in current USD \$ billions)

\begin{tabular}{|l|r|r|r|r|r|}
\hline \multicolumn{1}{|c|}{ Category } & $\mathbf{1 9 9 5}$ & $\mathbf{2 0 0 0}$ & $\mathbf{2 0 0 5}$ & \multicolumn{1}{c|}{$\mathbf{2 0 1 0}$} & \multicolumn{1}{c|}{$\mathbf{2 0 1 3}$} \\
\hline World & 3901 & 5079 & 8130 & 11409 & 13866 \\
\hline Industrialized countries & 3218 & 4015 & 5967 & 7579 & 8929 \\
\hline Emerging industrial countries & 654 & 938 & 1944 & 3451 & 4526 \\
\hline LDCs & 7 & 14 & 24 & 49 & 39 \\
\hline ODCs & 24 & 223 & 295 & 330 & 372 \\
\hline $\begin{array}{l}\text { \% value of manufactured exports of } \\
\text { LDCs/value of world manufacturing } \\
\text { exports }\end{array}$ & $0.18 \%$ & $0.28 \%$ & $0.30 \%$ & $0.43 \%$ & $0.28 \%$ \\
\hline
\end{tabular}

UNIDO, 2016, Table 1.3

The implication that can be deduced from Table 5 is that, without building their industrial capabilities, it is unlikely that the LDCs will meet the SDGs by 2030, particularly SDG 9 on industry, innovation and infrastructure. Large and sustained public and private investments would be required to build the productive capacities of their manufacturing sector and, subsequently to provide decent jobs for millions of young people who enter the labour market every year. Building productive capacities of the manufacturing sector in the LDCs will also expand their fiscal revenues needed for increasing their public investments. 


\subsection{Trend of current account balance}

Reflecting their weak export capabilities, the LDCs in different regions showed increasing trend in their current account deficits (See Table 6). The current account deficit increased from USD 12,691 million in 2005 to USD 74,876 million in 2014. The highest deficits were in the Asian LDCs which increased from USD 5785 million in 2005 to USD 37499 million in 2014 (UNCTAD, 2015, p.4). The deteriorating trend in the current account balance was mainly due to a strong worsening of service trade balance which increased from USD 16631 million in 2005 to USD 44255 million in 2014 (UNCTAD, 2014, p.4). Overall, the deficits in the current account in the LDCs were because of lack of diversification in their exports. The LDCs are thus constrained by foreign exchange in their efforts to import capital goods needed for their development. The foreign exchange constraint is an important aspect of development neglected in the neoliberal trade theory. Meeting the aspirations of the 2030 Agenda for sustainable development in the LDCs implies that the LDCs have yet to build their productive capacities, particularly the productive capacities of their manufacturing and agricultural sectors through increased public and private investments.

Table 6: Current account balance of the LDCs 2005-2014, selected years (Millions of USD)

\begin{tabular}{|l|c|c|c|c|c|c|}
\hline \multicolumn{1}{|c|}{ Category } & $\mathbf{2 0 0 5}$ & $\mathbf{2 0 1 0}$ & $\mathbf{2 0 1 1}$ & $\mathbf{2 0 1 2}$ & $\mathbf{2 0 1 3}$ & $\mathbf{2 0 1 4}$ \\
\hline Exports of goods \& services & 95604 & 194428 & 238579 & 244271 & 257094 & 256424 \\
\hline Imports of Goods \& services & 109295 & 225028 & 270027 & 292440 & 311147 & 331300 \\
\hline Current Account Balance & -12691 & -30600 & -31448 & -48169 & -54053 & -74876 \\
\hline
\end{tabular}

Source: UNCTAD 2015, p.4

\subsection{External resource gap}

Adequate domestic saving is central to economic growth because it determines the level of domestic investment. Low domestic saving is thus, a cause of concern because it reflects a weak economy and low level efficiency of financial intermediation (Ndikumana and Blankson, 2015). As shown in Table 7, one of the long-standing characteristics of the LDCs is their high dependence on external finance, resulting from the increasing gaps between their required investments and domestic savings. The LDCs as a group need external resource equivalent to $15 \%$ of their GDP to finance their current levels of investment (UNCTAD, 2012, p.8). The rationale is that foreign resources play a vital role in promoting economic development by relaxing the countries" "savings gaps" and "foreign exchange gaps". Table 7 shows that gross fixed capital formation in the LDCs which was 20.6\% of their GDP during the period 2002-2008, marginally decreased to $26.3 \%$ of their GDP in 2013. But the figure was much lesser than the gross fixed capital formation in the ODCs, which was $30.6 \%$ of their GDP in 2013. The gross domestic savings of the LDCs which was $18.9 \%$ of their GDP during 2002-2008 marginally increased to $19 \%$ in 2013 . However, the figure was much lesser than the gross domestic saving of ODCs, which was $33.8 \%$ of their GDP in 2013. The external resource gaps in the LDCs as a group deepened further from -1.7 percent of their GDP during the period 2002-2008 to -7.2 percent in 2013. 
IRA-International Journal of Management \& Social Sciences

Table 7: Gross Fixed capital formation, gross domestic savings and external resource gap, 20022013, selected years (Percent of GDP)

\begin{tabular}{|l|c|c|c|c|c|c|c|c|c|c|c|c|}
\hline & \multicolumn{3}{|c|}{ Gross Fixed Capital Formation } & \multicolumn{3}{c|}{ Gross Domestic Saving } & \multicolumn{3}{c|}{ External Resource Gap } \\
\hline & $\mathbf{2 0 0 2 - 0 8}$ & $\mathbf{2 0 1 0}$ & $\mathbf{2 0 1 2}$ & $\mathbf{2 0 1 3}$ & $\mathbf{2 0 0 2 - 0 8}$ & $\mathbf{2 0 1 0}$ & $\mathbf{2 0 1 2}$ & $\mathbf{2 0 1 3}$ & $\mathbf{2 0 0 2 - 0 8}$ & $\mathbf{2 0 1 0}$ & $\mathbf{2 0 1 2}$ & $\mathbf{2 0 1 3}$ \\
\hline LDCs & 20.6 & 23.7 & 26 & 26.3 & 18.9 & 18.5 & 19 & 19 & -1.7 & -5.1 & -7.1 & -7.2 \\
\hline $\begin{array}{l}\text { African } \\
\text { LDCs } \\
\text { \&Haiti }\end{array}$ & 19.5 & 23 & 25.4 & 25.5 & 19.3 & 17.8 & 17.8 & 17.2 & -0.2 & -5.1 & -7.6 & -8.4 \\
\hline Asian LDCs & 22.9 & 25.1 & 27.2 & 27.7 & 17.9 & 19.3 & 20.6 & 21.8 & -5 & -5.8 & -6.6 & -5.9 \\
\hline Island LDCs & 12.2 & 18.8 & 20.1 & 20.3 & 30.8 & 35.7 & 32.8 & 35.7 & 18.6 & 16.9 & 12.7 & 15.4 \\
\hline ODCs & 26.1 & 29.8 & 30.4 & 30.6 & 32.3 & 34.5 & 34.1 & 33.8 & 6.2 & 4.7 & 3.6 & 3.3 \\
\hline
\end{tabular}

UNCTAD, 2015, Table 4, p.1

The low gross domestic saving in the LDCs was basically because of their low per capita incomes. The low level of their financial sector development and their weak financial intermediation also contributed to their low domestic savings. Over the study period, the level of investments in the LDCs were below $25 \%$ of their GDP, which is considered a threshold necessary for achieving real GDP growth rates of 7\%-8\% percent in order to have an impact on poverty reduction (UNCTAD, 2012, p.4). Thus mobilization of adequate domestic savings would be one of the biggest challenges of the LDCs in implementing the 2030 Agenda for sustainable development. Despite their fragile economic growths, domestic saving is still potentially the biggest reliable source of financing the SDGs in the LDCs. To this end, the LDCs need more policy space to design and implement their policies for optimal use of available resources in a way that would lead to virtuous circle of high capital accumulation, increased investment, sustained economic growth and reduction in poverty ( UNCTAD, 2007, pp.4-5).

\subsection{Dependence on Official Development Assistance (ODA)}

The small sizes of the economies of the LDCs in terms of their GDP and their high vulnerability to external shocks were translated into low levels of their per capita incomes and, consequently to low levels of their domestic savings and investments. With their limited domestic savings, it has become difficult for the LDCs to increase their investments to sustain high economic growth rates (SESRTCIC, 2006). The LDCs have remained highly dependent on external financial resources, including official development assistance (ODA), foreign direct investment, external borrowing and private in flows such as remittances. Table 8 shows that the total external financial inflows to the LDCs increased from USD 17363 million in 1990 to USD 29901 million in 2006. Inflows of ODA to the LDCs constituted over 90\% of the total financial inflow. Their high dependency on ODA suggests that (i) the LDCs were unable to mobilize adequate domestic savings to meet their investment needs. (ii) The LDCs lacked the ability to access world financial markets to fill their external resource gaps.

Table 8: Financial flows to LDCs, 1990-2006 (\$ millions, net)

\begin{tabular}{|l|c|c|c|c|c|c|}
\hline & $\mathbf{1 9 9 0}$ & $\mathbf{1 9 9 5}$ & $\mathbf{2 0 0 0}$ & $\mathbf{2 0 0 4}$ & $\mathbf{2 0 0 5}$ & $\mathbf{2 0 0 6}$ \\
\hline Total financial inflow to LDCs & 17363 & 16713 & 13694 & 27077 & 25997 & 29901 \\
\hline Inflow of ODA & 16623 & 15143 & 12621 & 25222 & 25882 & 28181 \\
\hline \% ODA/Total financial flow & $95.70 \%$ & & $92.20 \%$ & $93 \%$ & $99.60 \%$ & $94.30 \%$ \\
\hline
\end{tabular}

Source: UNCTAD, 2008, p.167, Table 29

Since 1999, inflow of ODA to LDCs has shown a major shift from building of economic infrastructure and productive capacities to social infrastructures such as health and education. The shift reflects donors' 
approach to poverty reduction. Although poverty reduction is desirable development goal, it has reduced the magnitude of ODA directed to the production sectors (UNCTAD, 2008). The effectiveness of ODA on sustainable growth, structural transformation and poverty reduction has also been very low. Studies indicate that over the past 30 years, most aid-dependent countries have exhibited growth rates averaging minus 0.2 percent per annum (Moyo, 2009, p.46). Africa has persistently received development assistance worth of almost 15 percent of its GDP. Yet, over 30 African countries are still categorized as least developed countries. A World Bank study found that as much as 85 percent of aid inflows were used for purposes other than that for which they were initially intended; foreign aid is often diverted to unproductive ventures (World Bank cited in Moyo, 2009, p.39). Foreign aid has also constrained freedom of action in policy design in the LDCs due to several conditionalities attached to it. Thus, it is plausible that foreign aid has to be replaced by market access for the exports of the LDCs till they graduate from the LDCs status. This approach would provide incentives to the countries to invest more for building their productive capacities and their human resources (UNCTAD, 2011).

\subsection{Inflow of foreign direct investments and their sectoral orientation}

The LDCs have liberalized their economies with the expectations that the inflow of FDI will bring a package of resources-- capital, technology, management and marketing know-how needed for their economic development (Sauvant and Mallampally, 2015). FDI flow to host countries are classified into natural-resource-seeking, market-seeking, efficiency-seeking and created-asset-seeking (Sauvant and Mallampally, 2015, p.240). Table 9 shows that during the period 2002-2008, inflow of FDI to the LDCs as a group was USD 9718 million, much lesser than the inflow of FDI to the ODCs, which was USD 339637 million. In 2014, the FDI inflow to LDCs reached USD 23239 million, still, much lesser than the inflow of FDI to the ODCs, which was USD 736234 million. Although the inflow of the FDI to LDCs showed an increasing trend, it was largely resource-seeking directed to natural resource exploration and extraction of minerals which had limited impact on employment creation and development on their economies. Under neo-liberal development model, the LDCs with their relatively low GDP per capita and low development of their human resources remained at a relative disadvantage in attracting other than natural-resource-seeking FDI (UNCTAD, 2014, p.33).

Table 9: Foreign direct investment inflows 2000-2014 (Millions of current dollars)

\begin{tabular}{|l|r|r|r|r|r|r|}
\hline & $\mathbf{2 0 0 2 - 0 8}$ & $\mathbf{2 0 1 0}$ & \multicolumn{1}{c|}{$\mathbf{2 0 1 1}$} & \multicolumn{1}{c|}{$\mathbf{2 0 1 2}$} & \multicolumn{1}{c|}{$\mathbf{2 0 1 3}$} & \multicolumn{1}{c|}{$\mathbf{2 0 1 4}$} \\
\hline LDCs & 9,718 & 23,774 & 21,852 & 23,524 & 22,372 & 23,239 \\
\hline African LDCs & 7,566 & 13,669 & 17,919 & 19,669 & 17,727 & 18,733 \\
\hline Asian LDCs & 2,064 & 9,721 & 3,614 & 3,624 & 4,498 & 4,435 \\
\hline Island LDCs & 88 & 384 & 319 & 231 & 102 & 70 \\
\hline ODCs & $3,39,637$ & $6,17,758$ & $6,93,025$ & $6,92,676$ & $7,55,485$ & $7,36,234$ \\
\hline
\end{tabular}

Source UNCTAD, 2015, Table 6, p. 7

\subsection{External debt burden of LDCs}

The LDCs have been borrowing from aboard to relax their foreign exchange constraints with the expectation to promote their economic growth through increasing their investments. Contrary to the expectation, the LDCs continued to accumulate external debt and to pay debt services for decades. The external debt of the LDCs which was USD 138.1 billion in 2001 increased to USD 158.9 billion in 2003 (UNCTAD, 2006, p.23). In 2012, the total external debt of the LDCs reached USD 183 billion (UN, 2013, p.4). The external debt of the LDCs is about twice as great as the debt burden of the ODCs (UNCTAD, 2006, p.23). Table 10 illustrates that the external debt of the LDCs as a group which was $53 \%$ of their gross national income (GNI) during the period 2000-2003 decreased to $25 \%$ in 2013 . The percentages of Debt in GNI were significantly lower than the critical limit of 80 percent used by international financial institutions for classifying highly indebted developing countries (UNCTAD, 2004, 
p.44). The external debt stock as percentage of exports decreased from $116.7 \%$ during the period 20052008 to $71.6 \%$ in 2013 , lesser than the critical value of $220 \%$ used internationally in defining developing countries as highly indebted (UNCTAD, 2004, p.44).

Table 10: External Debt burden of LDCs, 2000-2013, selected years

\begin{tabular}{|c|c|c|c|c|c|c|c|c|c|c|c|c|}
\hline \multirow[t]{2}{*}{ Category } & \multicolumn{4}{|c|}{$\begin{array}{l}\text { Total external debt stock } \\
\text { as \% of GNI (EDT/GNI) }\end{array}$} & \multicolumn{4}{|c|}{$\begin{array}{l}\text { Total external Debt } \\
\text { Stock/total exports of } \\
\text { goods \&services } \\
\text { (EDT/XGS) }\end{array}$} & \multicolumn{4}{|c|}{$\begin{array}{l}\text { Total Debt Service as\% } \\
\text { exports(EDST/XGS) }\end{array}$} \\
\hline & $\begin{array}{c}\text { 2000- } \\
03\end{array}$ & 2011 & 2012 & 2013 & $\begin{array}{c}\text { 2005- } \\
08\end{array}$ & 2011 & 2012 & 2013 & $\begin{array}{c}\text { 2005- } \\
08\end{array}$ & 2011 & 2012 & $\begin{array}{c}201 \\
3\end{array}$ \\
\hline LDCs & 52.99 & 23.9 & 23.8 & 24.9 & 116.7 & 76.4 & 77.4 & 71.6 & 5.9 & 3.6 & 4 & 4.7 \\
\hline $\begin{array}{l}\text { African } \\
\text { LDC } \\
\text { \&Haiti }\end{array}$ & 69.56 & 27 & 26.9 & 29.1 & 114.6 & 71 & 71.7 & 64 & 5.7 & 3,6 & 3.9 & 4.7 \\
\hline $\begin{array}{l}\text { Asian } \\
\text { LDCs }\end{array}$ & 32.62 & 19.6 & 19.2 & 18.8 & 126.4 & 93.2 & 94.9 & 89.6 & 4 & 3.4 & 3.4 & 4.5 \\
\hline $\begin{array}{l}\text { Island } \\
\text { LDCs }\end{array}$ & 40.23 & 13.1 & 14.3 & 8.9 & 87.7 & 19.7 & 20.1 & 12.1 & 2.8 & 0.6 & 1.2 & 1.3 \\
\hline ODCs & 21.69 & 15.5 & 16.6 & 17.2 & 41.35 & 42.3 & 44.7 & 46.7 & 6.8 & 4.9 & 5.1 & 5 \\
\hline
\end{tabular}

Source: UNCTAD 2015, Table 8.p.8

Taking into account the poor performance of their economies, debt service takes up a large part of the LDCs' scarce budgetary resources. Debt service has limited the investment capability of the LDCs, and is an obstacle for their economic growth, poverty eradication. The LDCs economic prospects and achievement of SDGs can thus be influenced considerably by progress in international debt relief efforts (ADB, 2003). The appropriate approach is a complete cancelation of all external debt of LDCs by all creditors in line with the commitment of the international community to provide resources to the LDCs in order strengthen their financing capabilities and to achieve the SDGs. Thus, instead of providing aid and extending further loans which have proved to be ineffective in addressing socio-economic problems of the LDCs, a better approach to the achievement of the SDGs by LDCs would be the cancellation of all external debts by all creditors so that the financial resources released would be invested for achieving SDGs.

\subsection{Human Development and poverty eradication}

Since 1990, the social dimension of the development process has gained special importance on the grounds that people should be actively involved in the process with greater access to better social services, mainly education and health care. The Human Development Index (HDI) measures social welfare based on three variables: longevity, education and income (UNDP, 2015) ${ }^{*}$ The HDI of the LDCs as a group which was 0.348 in 1990 increased to 0.502 in 2014. Based on HDI, the LDCs are ranked in the low human development because of inadequate investment. The implication is that the LDCs still have to build their human development through increased investments in their social sectors particularly in education and health care. 


\section{Discussion and implications for the implementation of the 2030 Agenda for Sustainable Development}

\subsection{Discussion}

This study reviewed the evidence of LDCs' economic performances while following neo-liberal approach to their development and, the implications for the implementation of the 2030 Agenda for sustainable development which is expected to be achieved by all countries by 2030 .

1. During the period 2002-2015, real GDP growth rates of the LDCs as a group showed a declining trend, reaching $5.2 \%$ in 2015. As the growth rates are dependent on commodity prices, external financing and weather conditions, the sustainability of the growths in the LDCs still remains fragile. The growths in the LDCs have not gone had in hand with the required development of their productive capacities, which need investments equal to or greater than $25 \%$ of their respective GDP to achieve $7 \%-8 \%$ growth rates that will have a great impact on their poverty reduction. Structural change in the economies of the LDCs was very slow. The share of agriculture in GDP decreased from $33 \%$ in 1991 to $25 \%$ in 2012 mainly because of de-agrarianization, the shrinking of the contribution of the agricultural sector for lack public and private investments. The share of industry increased from $23 \%$ in 1991 to $31 \%$ in 2012 , due to the increased contribution of non-manufacturing industries such as mining, utilities and construction. The service sector had the greatest share in GDP constituting $44 \%$ in 2012, with no appreciable structural transformation in favour of manufacturing sector. This is shown by the fact that agriculture employed $65 \%$ of their labour force in 2012 but its contribution to GDP was lesser than the service sector, which employed $26 \%$ of their labour force. The LDCs moved from a state in which their agriculture had a high share in GDP to one in which the service sector, particularly low-productivity activities within the service sector, dominated the GDP.

2. The composition of the LDCs' exports also showed little diversification. During the period 2012$2014,76.8 \%$ of their export earnings were from the primary commodities, while export earnings from manufacturing sector constituted around 23\%. The share of export earnings of the LDCs from manufacturing sector were insignificant constituting less than one percent of the world export earnings from the sector during the period 1995-2013. The large share of primary commodities in exports brings a significant exposure of the LDCs' economies to the risks of external shocks, such as the fluctuating trends in international commodity prices and adverse weather conditions. The LDCs weak export capabilities and the high import intensity of their economies resulted into increasing external resource gaps, making the countries to heavily depend on foreign resources inflows.

3. Reflecting their persistent deficits in their current account balances, the LDCs increased their reliance on foreign savings to fill their investment-domestic saving gaps. The external resource gap increased from 1.7 percent of their GDP during the period 2002-2008 to 7.2 percent in 2013. Inflow of ODA to the LDCs constituted the dominant source of their external financing, constituting more than $90 \%$ of the total financial inflows during the period 1990-2006. The high dependency on ODA suggests that (i) the LDCs were unable to mobilize adequate domestic savings to meet their investment needs (ii) the LDCs lacked the ability to access world financial markets to fill their external resource gaps. However, the ODA/foreign aid was ineffective in enhancing sustained economic growth and structural transformation in these countries. Foreign aid has rather constrained the policy space of the LDCs' governments because of the conditionalities attached to it. The inflow of FDI to the LDCs was largely resource-seeking directed to natural resource exploration and extraction of minerals with limited effects on transfer of technology, employment creation and poverty reduction. The LDCs with their relatively low GDP per capita and low development of their human resources and infrastructures are at a relative disadvantage in attracting other than natural-resource-seeking. 
4. Over the study period, the LDCs continued to borrow from external sources to fill external resource gaps. As a result, they were forced to accumulate external debts.The external debt as a percentage of their GNI which was 53\% during the period 2000-2003 decreased to 25\% in 2013. The external debt stock as percentage of their exports decreased from $116.7 \%$ during the period $2005-2008$ to $71.6 \%$ in 2013. However, the debt service still takes up a large part of the LDCs' scarce budgetary resources, and it is an obstacle for their economic growth, poverty eradication and achievement of SDGs. With respect to their human development, the HDI of the LDCs as group increased from 0.35 in 1990 to 0.50 in 2014. The LDCs are ranked under low human development based on their HDI. The implication is that economic growths in the LDCs were not transformative and pro-poor because the growths were not translated effectively into substantial poverty reduction and improvement of human development through trickledown effects. Around $75 \%$ of the LDCs population continue to live in poverty, nearly $30 \%$ of their population are undernourished, and nearly two-thirds of the population have no access to clean water supply and sanitation facilities.

5. The conclusion is that the LDCs are highly vulnerable to external shocks that result from trade openness and from the low productive capacities perspective. They are the least prepared for a full integration into the global trading reality. Thus, the LDCs do not seem to move along a sustainable development path to meet the SDGs while adopting the inappropriate neo-liberal development model. The LDCs are still locked into a low equilibrium trap characterized by fragile economic growths, distorted structural transformation, low domestic resource, high dependence on external financing, high dependence on primary commodity exports, high external debt burden and debt services, low human development. The existing production and trade structure offer very limited opportunities for capital accumulation needed to build their productive capacities and to expand productive employment that would result into sustained economic growth, structural change, export diversification and poverty alleviation in line with the SDGs. An alternative to the neoliberal approach is the developmental state which focuses on building productive capacities to make the LDCs more beneficiaries of globalization and economic liberalization. In the developmental state approach, the governments of the LDCs are expected to demonstrate their commitment to economic development and to design policies and institutions that focus on building productive capacities and enhancing structural transformation that would enable their countries to achieve the SDGs .

\subsection{Implications for the implementation of the 2030 Agenda for Sustainable Development}

Implementation of the 2030 Agenda for sustainable development is an integrated agenda for economic, social, environmental and security development. Coherent implementation of all SDGs is now needed to foster structural changes, boost growth, and create jobs and to achieve inclusiveness and poverty eradication in the LDCs. In line with these, there are important implications for the LDCs and the international community during implementation of the SDGs:

1. The LDCs would be required to expand their policy spaces and undertake proactive complementary policies for building their productive capacities to achieve the expected positive benefits of trade liberalization in terms of sustained economic growth, poverty reduction, structural transformation, export diversification and financiering capabilities to meet the SDGs by 2030.

2. Strengthening south-south cooperation would help the LDCs to enhance their mutual development partnership, particularly in the areas of trade, investment, transfer of technology and human resource development. The cooperation will also contribute to the building of their productive and financing capacities and to the achievement of SDGs. 
3. LDCs are responsible for their development and financing the SDGs. They would be required to extensively tap their domestic potentials to substantially increase their domestic savings to the level of $25 \%$ or above of their GDP to sustain $7 \%-8 \%$ growth rates to reduce or eliminate their poverty.

4. The LDCs would be required to prioritize the SDGs and, select a few SDGs depending on their own circumstances. This is because the LDCs lack resources and are unable to meet the investment needs of all the SDGs. The selected SDGs need to be synchronized with their respective national development plans and targets. This approach will help the LDCs to estimate their domestic financing needs for the selected SDGs as well as their external resource gaps that could be met by mobilizing foreign resources.

5. Given the present state of affairs in the LDCs, their development needs exceed their domestic resources. The prospects of economic growth and achievement of SDGs in the LDCs will be influenced considerably by progress in international debt relief efforts and access of LDCs' exports to markets of the developed countries. The best approach to debt management would be cancelation of all external debt of the LDCs by all creditors. This approach is in line with the commitment of the international community to provide resources to the LDCs required for financing the SDGs and to create poverty free global society by 2030 . Cancellation of all external debt would release investible capital and, subsequently increase investment capabilities of the LDCs. This, in turn would enable the LDCs to move along a sustained growth path that would enable them achieve the SDGs.

6. Increase access for the exports of the LDCs to markets of the developed countries by expanding their productive capacities and import capabilities will have more contribution to their economic growth, poverty eradication and export diversification. Thus, replacing foreign aid by market access for their exports will provide a better incentive for the LDCs to increase their investments for strengthening their productive capacities that ensure sustained economic growth and eventually eliminate poverty.

7. Sustainable development cannot be realized without peace and security in all countries, including the LDCs. SDG 16 underscores promotion of peaceful and inclusive societies. With regards to the LDCs, there are several countries, particularly in Africa that has been adversely affected by long-staying conflicts of different nature: Ethio-Eritrean unsettled border conflict, Somalia crisis, and the conflicts in South Sudan, Democratic Republic of Congo and Central Africa Republic. These conflicts are costly in terms of human suffering and opportunities lost in terms of development. The governments of the countries affected by conflicts must thus demonstrate their commitment to maintain lasting peace and stability in their respective countries by resolving the conflicts through appropriate means which is acceptable by all parties affected by the conflicts. The UN is also expected to live up to its mandate and its Charter to secure the world from all hegemonic powers which trigger conflicts in different regions of the world and to uphold global social justice in order to have a poverty free secured and peaceful world by 2030 and beyond.

\section{References}

1) Abubakar, M. B. 2010. Globalization and Developing Economies: Problems and Prospects. International Journal of Economic Development Research and Investment Vol. 1, No 1. Pp.163-174.

2) Ackerman, Frank and Gallagher, Kevin P. 2008.The Shrinking Gains from Global Trade Liberalization in Computable General Equilibrium Models: A Critical Assessment. International Journal of Political Economy, vol. 37, no. 1 pp. 50-77.

3) African Development Bank (ADB) 2003. African Development report 2003: Globalization and Africa's Development. Oxford University Press: Oxford 
4) African Development Bank (ADB) 1999. African Development Report 1999. Infrastructure Development in Africa. Oxford University press; Oxford.

5) Afzal, Muhammad 2012. Do Structural Transformation and Trade Liberalization cause Economic Growth in Pakistan? Applied Econometrics and International Development, Vol. 12-1, pp.187-198

6) Alemayehu, Makonnen 2000. Industrializing Africa: Development Options and Challenges for the $21^{\text {st }}$ Century. African World press, Inc: New Jersey.

7) Asiedu, Michael Kwame 2013.Trade Liberalization and Growth: The Ghanaian Experience. Journal of Economics and Sustainable Development Vol.4, No.5, 2013, pp.125-135.

8) Babatunde, Musibau Adetunji 2009. Can Trade Liberalization Stimulate Export Performance in SubSaharan Africa? Journal of International and Global Economic Studies, 2(1), June 2009, 68-92 Can Trade Liberalization Stimulate Export Performance.

9) Bhattacharya, Debapriya and Hossain, Syed Saifuddin 2011. Least Developed Countries in the Next Decade. What is there in the Istanbul Programme of Action? International Policy Analysis /FES Geneva

10) Bergés, Ame R.2007. Trade Liberalization and Market Access: Analyzing Dominican Export Performance during the Twentieth Century. QEH Working Paper Series- QEH Working Paper Number 161.

11) Dercon, Stefan 2007. Globalization and Marginalization in Africa: Poverty, Risk and Vulnerability in Rural Ethiopia. United Nations University -World Institute for Development Economic Research (UNU-WIDER) Research paper No.2007/73.

12) Economic commission of Africa (ECA) 2013. Two Decades of Trade Liberalization and Market Expansion in Eastern Africa-Towards a New Economic Geography?" Addis Ababa.

13) Evans, Peter and Sewell, William H. 2011. The Neoliberal Era: Ideology, and Social Effects. Prepared for Social Resilience in the Neo-Liberal Era, Cambridge University Press.

14) Farah, Ibrahim, Sylvia Kiamba and Mazongo Kesegofetse 2011. Major challenges facing Africa in the $21^{\text {st }}$ century: A few provocative remarks. A paper presented At the International Symposium on Cultural Diplomacy in Africa - Strategies to confront the Challenges of the 21st Century: Does Africa have what is required? Berlin, $14^{\text {th }}-17^{\text {th }}$ July, 2011.

15) Hammouda, Hakim Ben and Jallab, Mustapha Sadni 2003. Trade Liberalization and Development: Lessons for Africa. A Paper prepared for United Nations Economic Commission for Africa: Africa Trade Policy center, Addis Ababa.

16) Hsque, T M. Shamsul 1999. The Fate of Sustainable Development Under Neo-liberal Regimes in Developing Countries .I international Political Science Review, Vol. 20, No. 2, 197-218

17) Jones, Charles I. 1998. Introduction to Economic Growth. W.W. Norton \&Company, Inc: New York.

18) Khor, Martin 2000. Globalization and the South: Some Critical Issues. United Nations Conference on Trade and Development (UNCTAD). Discussion paper No. 147.Gneva.

19) King, D.S. (1987). The New Right: Politics, Markets and Citizenship. Chicago, IL: Dorsey Press.

20) Kumssa, Asfaw and Jones, John F. 2015. Post-independence African Policy: African Socialism and the Organization of African Unity. Public Administration Research; Vol. 4, No. 1, pp. 12-23.

21) Lapeyre, Fredric 2004. Globalization and structural adjustment as a development tool. Working Paper No.31.Policy Integration Department, World Commission on the Social Dimension of Globalization. International Labour Office: Geneva

22) Leftwich, Andrian 2000. States of Development: On the Primacy of Politics of Development. Polity Press: Cambridge

23) Montes, Manuel F. 2014. Obstacles to Development in the Global Economic System. South Center Research Paper 51 July 2014, Geneva.

24) Moyo, Dambisa 2009. Dead Aid: When Aid Is Not Working And How There Is A Better Way for Africa. Farrar, Straus and Giroux: New York

25) Nayyar, Deepak 2006. Development through Globalization? UNU World Institute for Development Economics Research (UNU-WIDER) Research Paper No. 2006/29 
26) Ndikumana, Leonce, and Blankson, Theresa M. 2015. Financing Domestic Investment in African Countries: Does the Source of Financing Matter? Journal of African Development (2015) 17:21-44

27) Pinstrup-Andersen, P. and S. Shimokawa. 2008. Do Poverty and Poor Health and Nutrition Increase the Risk of Armed Conflict Onset? Food Policy 33, pp. 513-520

28) Sauvant, Karl P and Mallampally, Padma 2015. Policy Options for Promoting Foreign Direct Investment in the Least Developed Countries .Transnational Corporations Review Volume 7 Number 3 pp. 237-268.

29) SESRTCIC 2006. Economic Problems of the Least Developed and Land -locked OIC Countries. Journal of Economic Cooperation, 27-3, PP. 51-120.

30) Siddiqui, Kalim 2012.Developing Countries' Experience with Neo-liberalism and Globalisation Research in Applied Economics Vol. 4, No. 4, pp.12-37.

31) South Center 2013. Post-2015 Development Agenda and Sustainable Development Goals: Perspectives of the South Center, Geneva.

32) Taleb, AWAD 2012. Trade Liberalization Policy and Growth: Is It working for Jordan? Regional and Sectoral Economic Studies Vol. 12-2 (2012), pp.161-172.

33) Tedaro, Michael P. And Smith, Stephen C. 2011. Economic Development. Eleventh Edition. Pearson: London.

34) Toye, J. (1991). "Is There a New Political Economy of Development?" In States or Markets? Neoliberalism and the Development Policy Debate (C. Colclough and J. Manor, eds.). New York: Oxford University Press.

United Nations Conference on Trade and Development (UNCTAD) 2015. The least Developed Countries Report 2015: Transforming rural Economies. UNCTAD: New York and Geneva.

a. 2015. Statistical Tables on Least Developed Countries -2015.

b. 2014. The Least Developed Countries Report 2014.Growth with Structural Transformation: A Post2015 Development Agenda. INCTAD: New York and Geneva

c. 2010. Pre-conference event for the fourth United Nations conference on the least Developed countries Palais des Nations, Geneva, 27-29 October 2010. From Brussels to Istanbul. Key development challenges facing the Least Developed Countries. Compilation of documents of conference events organized by UNCTAD in preparation for the Fourth United Nations Conference on the Least Developed Countries (LDC-IV) Istanbul, Turkey: 9-13 May 2011.

d. 2012. The Least Developed Countries Report 2012: Harnessing Remittances, and Diaspora Knowledge to build productive Capacities. UNCTAD: New York and Geneva

e. 2011. From Brussels to Istanbul: Key development challenges facing the Least Developed Countries. Compilation of documents of pre-conference events organized by UNCTAD in preparation for the Fourth United Nations Conference on the Least Developed Countries (LDC-IV), Istanbul, Turkey: 9-13 May 2011.

f. 2008. The Least Developed Countries Report 2008: Growth, Poverty, and the Terms of Development Partnership. UNCTAD: New York and Geneva.

g. 2007. Economic Development in Africa. Reclaiming Policy Space: Domestic Resource mobilization and Developmental States. UNCTAD. New York and Geneva.

h. 2006. The least Developed Countries Report 2006: Developing productive capacities. UNCTAD: New York and Geneva.

i. 2005. Towards a New Trade "Marshall Plan" for Least Developed Countries .How to Deliver on the Doha Development Promise and Help Realize the UN Millennium Development Goals? Trade, Poverty and Cross-cutting Development Issues Study Series No.1 UNCTAD/DITC/TAB/POV/2005/1, Geneva

j. 2005. Trade liberalization and Economic Reform in Developing countries: Structural change or Deindustrialization? UNATAD Discussion Paper no.179.Geneva. 
k. 2004. Economic Development in Africa, Debt Sustainability: Oasis or Mirage? UNCTAD: new York and Geneva.

1. 2004. The Least Developed Countries Report 2004: Linking International Trade with Poverty Reduction. UNCTAD: New York and Geneva.

m. 1999. Future of Multilateral Trade Negotiations: Handbook for Trade Negotiators for the LDCs. UNCTAD: Geneva and New York.

United Nations (UN) 2016. Committee for Development Policy .Development Policy and Analysis Division, Department of Economic and Social Affairs, New York.

a.

2015. Transforming Our World: The 2030 Agenda for Sustainable Development: Draft Resolution referred to the United Nations for the adoption of the post-2015 development agenda by the general assembly at its sixty-ninth session.

b. 2015. Department of Economic and Social Affairs and Committee for Development Policy 2015. Handbook on the Least Developed Country Category: Inclusion, Graduation and Special Support Measures: New York.

c. 2013. General Assembly A/68/203. External debt sustainability and development. Report of the Secretary-General. Sixty-eighth session Item 17 (c) of the provisional agenda Macroeconomic policy questions. New York.

d. 2011. Fourth United Nations Conference on the Least Developed Countries. Report of the Fourth United Nations Conference on the Least Developed Countries, Istanbul, Turkey, 9-13 May 2011.

e. United Nations Industrial Development Organization (UNIDO) 2016. Industrialization in Africa and Least Developed Countries. Boosting growth, creating jobs, promoting inclusiveness and sustainability. A Report to the G20 Development Working Group by UNIDO .New York.

f. United Nations Development Programme (UNDP) 2015. Human Development Report 2015: Work for Human Development. Oxford University Press: New York

g. Wenjing, Wang et al. 2012. The impact of globalization on African countries economic development. African Journal of Business Management Vol.6 (44), pp. 11057-11076. 